\title{
Phytochemical Profile of Telfairia occidentalis Leaf Grown in Soilless and Soil Media using HPLC
}

\author{
Okonwu, K; Akonye, LA; Mensah, SI \\ Department of Plant Science and Biotechnology, University of Port Harcourt, \\ P.M.B. 5323, Port Harcourt, Nigeria. \\ Corresponding author (Email: kalu.okonwu@uniport.edu.ng)
}

Received: November 6, 2017 Accepted: November 24, 2017 Published: December 14, 2017

doi:10.5296/jas.v5i4.12296

URL: https://doi.org/10.5296/jas.v5i4.12296

\begin{abstract}
The phytochemical components of Telfairia occidentalis Hook F. leaf grown in soil (HS) and soilless (NM) media were assessed using High Performance Liquid Chromatography (HPLC). The media used for the soil medium and soilless medium were humus soil and hydroponic solution, respectively. White-sand from the river was used to raise the seedlings before transferring into hydroponic solution. The plants were allowed to grow for a month for both HS and NM. The phytochemicals assessed were hydrogen cyanide, phytate, saponin, tannin, trypsin inhibitor, flavonoids and alkaloids. Standard procedures were followed in the analyses. The assessed phytochemicals for T. occidentalis revealed the following: phytate $(9.774 \mathrm{ppm}$; $8.857 \mathrm{ppm}$ ), tannin (2.546 ppm; $2.127 \mathrm{ppm})$, oxalate (5.897 ppm; $5.927 \mathrm{ppm})$, saponin (6.829 ppm; $7.253 \mathrm{ppm})$, trypsin-inhibitor (1.290 ppm; $2.584 \mathrm{ppm})$, total flavonoids (10.019 g/100g; $8.064 \mathrm{~g} / 100 \mathrm{~g})$, and total alkaloids (11.614 g/100g; $9.082 \mathrm{~g} / 100 \mathrm{~g})$ for NM and HS media, respectively. Hydrogen cyanide content of $T$. occidentalis $(0.001 \mathrm{ppm})$ was the same in both NM and HS. The phytochemical profile of $T$. occidentalis leaf varied in both media. Hydroponically grown $T$. occidentalis leaf had higher concentration of phytochemicals when compared to orthodox use of soil for cultivation of vegetable.
\end{abstract}

Keywords: Soilless, soil, growth, phytochemicals, Telfairia occidentalis

\section{Introduction}

Many chemical components of natural food products have been identified as toxicants and some of these include cyanogenic glycoside, hemagglutinin, saponin, gossypol, goitrogen, trypsin-inhibitor, oxalates, phytates and antivitamins. Amino acids serve as building blocks in the production of alkaloids, a secondary metabolites, which offers chemical resistance in plants that makes it biologically useful for consumption (Moran-Palacio et al., 2014). 
Alkaloids as secondary metabolites exit in the form of salts with organic acids. They are elementary natural products occurring mainly in plants. Cytochrome oxidase inhibitor such as cyanide actively impedes the breathing system of organisms making cyanogenic glycosides important component of food. Tannins have the ability to change the colour of natural food and processed products. Also, numerous effects are associated with products when tannins attach to proteins and carbohydrates. Enzyme inhibitors remain inherent natural chemical components found in both plant and animal tissues which tends to hamper the activities of certain enzymes from performing their function of breaking down complex molecules into simpler molecules. Studies have shown that anti-nutritional component of food impedes growth with consequent complications in experimental organisms (Chunmei et al., 2010). Flavonoids which are polyhydroxylated compounds are known as antioxidants and are also involved in the management of cardiovascular disorders (Onyeka et al., 2010). Phytates have been reported to occur naturally in food as salts of potassium, magnesium and calcium (Zhou and Erdman, 1995). Important minerals in food substances such as calcium, iron, magnesium and zinc react with phytic acid to form insoluble salts thereby making its absorption into the blood stream inaccessible. Phenols are secondary metabolites synthesized by the plants. These are potentially effective antioxidants which have the ability to prevent free radicals from harming organisms (Velioglu et al., 1998; Chu et al., 2002; Kaur and Kapoor, 2002; Materska and Perucka, 2005; Nadeem et al., 2011).

Kajihausa et al. (2010) reported that food intake from natural sources is on the increase because of its importance to the well-being of humans. In some parts of Nigeria, the leaves of Telfairia occidentalis are extracted and used to cure and control illnesses such as convulsion, respiratory diseases, fever and headaches (Iwu et al., 1999; Ayandele and Adebiyi, 2007). This leafy vegetable is useful and serve several possesses in the nutritional formulations for Africans, mostly Nigerians.

The choice of T. occidentalis leaves as source of medicine and part of everyday meal of many people led to the study. It is aimed at assessing and quantifying of phytochemicals inherent in T. occidentalis grown in soilless and soil media using high performance liquid chromatography (HPLC).

\section{Materials and Methods}

\subsection{Source of Materials}

The seeds of T. occidentalis were sourced from a farm in Choba. The seeds were divided into two batches and planted in white sand from the Choba River and top humus soil $(0-25 \mathrm{~cm})$ from a garden in University of Port Harcourt respectively as a medium for germination. The two weeks old seedlings from the white sand were transferred into a non-circulating hydroponic nutrient system. The nutrient solution used for the hydroponic was bicfarmsconcept formulation. The plants in both soilless medium (NM) and soil medium (HS) were allowed to stand for a month, when it can be harvested to prepare food.

\subsection{Determination of Various Compounds}

The matured leaves were harvested and used to determine the phytochemicals, flavonoids, 
alkaloids, organic acids, glycosides and phenolic compounds of T. occidentalis grown in both geoponic and hydroponic medium.

\subsubsection{Cyanogenic Glycosides}

Sample (5 g) was ground into a paste. The paste was transferred into a corked conical containing $50 \mathrm{~mL}$ distilled water and left overnight to facilitate cyanide extraction. The extract was filtered and the filtrate used for cyanide determination. To $1 \mathrm{~mL}$ of the filtrate, $4 \mathrm{ml}$ alkaline picrate was added and incubated in a water bath for 5 minutes. After colour development (reddish brown colour), the absorbance of the corked test tube read in spectrophotometer at $490 \mathrm{~nm}$. Also, the absorbance of the blank containing only $1 \mathrm{~mL}$ distilled water and $4 \mathrm{~mL}$ alkaline picrate solution. Then, the cyanide content was extrapolated from a cyanide standard curve.

\subsubsection{Phytate}

The rapid determination of phytate was according to the method of Oberlease et al. (1962).

The plant material was extracted with $0.2 \mathrm{~N} \mathrm{HCl}$ such that we have 3-30 $\mu \mathrm{g} / \mathrm{mL}$ phytate solution. The extract $(0.5 \mathrm{ml})$ was pipetted into a test tube fitted with a ground-glass stopper and $1 \mathrm{~mL}$ of ferric solution was added. The test tube was heated in a boiling water bath for 30 minutes. Sample was cooled in ice water for 15 minutes and allowed to adjust to room temperature. The content of the tube was mixed and centrifuged for 30 minutes at $3000 \mathrm{rpm}$. The supernatant $(1 \mathrm{~mL})$ was transferred to another and $1.5 \mathrm{~mL}$ of 2, 2-Bipyridine solution. Absorbance of the solution measured at $519 \mathrm{~nm}$ against distilled water. The method had to be calibrated with the reference solutions as a substitute for the sample solution with each set of analyses. Preparations of the calibration curve was carried out by plotting the concentrations of the reference solutions against their corresponding absorbance. Then the absorbance of the test sample was used to obtain the concentration from the calibration curve.

\subsubsection{Tannin}

The Folin-Denis spectrophotometric method was used to determine tannin. The method was described by Pearson (1976). One (1) gram of the sample was dispersed in $10 \mathrm{~mL}$ distilled water and agitated. This was left to stand for $30 \mathrm{~min}$ at room temperature, being shaken every 5 minutes. At the end of the 30 minutes, it was centrifuged and the extract gotten. $2.5 \mathrm{~mL}$ of the supernatant (extract) was dispersed into a $50 \mathrm{ml}$ volumetric flask. Similarly, $2.5 \mathrm{~mL}$ of standard tannic acid solution was dispersed into a separate 50ml flask. A $1.0 \mathrm{~mL}$ Folin-Denis reagent was measured into each flask, followed by $2.5 \mathrm{~mL}$ of saturated $\mathrm{NaCO}_{3}$ solution. The mixture was diluted to mark in the flask $(50 \mathrm{~mL})$, and incubated for $90 \mathrm{~min}$ at room temperature. The absorbance was measured at $250 \mathrm{~nm}$ wavelength in a Genway model 6000 electronic spectrophotometer. Readings were taken with the reagent blanket zero. The tannin content was given as follows.

$\%$ Tannin-An/As x C x 100/w x Five

Where, $A n=$ absorbance of test sample; As = absorbance of standard solution; $\mathrm{C}=$ concentration of standard solution; $\mathrm{W}=$ weight of sample used; $\mathrm{Vf}=$ total volume of extract; 


\section{$\Lambda$ Macrothink}

$\mathrm{Va}=$ volume of extract analysed

\subsubsection{Enzyme Inhibitors}

The trypsin inhibitor activity (TIA) assay via spectrophotometric method described by Arntfield et al., (1985).

Extraction of sample: Test sample weight of $1.0 \mathrm{~g}$ was dispersed in $50 \mathrm{ml}$ of $0.5 \mathrm{M} \mathrm{NaCl}$ solution, the mixture was stirred for 30 minutes at room temperature and centrifuged. The supernatant was filtered through filter paper (Whatman No. 41) and the filtrate used for the assay. To $10 \mathrm{~mL}$ of the substrate in a test tube, $2 \mathrm{ml}$ of the standard trypsin solution was added and a blank of $10 \mathrm{~mL}$ of the same substrate in a test tube with no extract added. The content of the test tubes were allowed to stand for at least 5 minutes and then measured at wavelength of $410 \mathrm{~nm}$. One trypsin unit inhibited is given by an increase of 0.01 absorbance units at 410 $\mathrm{nm}$, given a $100 \mathrm{~mL}$ of the mixture. That is one trypsin unit inhibited (TUI) is equal to an increase of 0.01 in absorbance unit at $410 \mathrm{~nm}$. The trypsin inhibitor activity is expressed as the number of trypsin units inhibited (TUI) per unit weight (g) of the sample analysed.

$$
\begin{array}{cc}
\mathrm{TUI} / \mathrm{mg} & =\frac{\text { Absorbance of Sample }}{\text { Absorbance of Standard }} \times 0.01 \mathrm{~F} \\
\mathrm{TUI} / \mathrm{mg} & =\frac{b-a}{0.01} \times \mathrm{F}
\end{array}
$$

Where $\mathrm{b}=$ absorbance of the test sample solution; $\mathrm{a}=$ absorbance of the blank (control); $\mathrm{F}=$ experimental factor, given by

$$
\mathrm{F}=\frac{1}{\mathrm{w}} \mathrm{X} \frac{\mathrm{Vf}}{\mathrm{Va}} \mathrm{XD}
$$

Where $\mathrm{w}=$ weight of the sample; $\mathrm{V} f=$ total volume of extract; $\mathrm{V}_{\mathrm{a}}=$ volume of extract used in the assay; $\mathrm{D}=$ dilution factor (if any)

\subsubsection{Oxalates}

This determination involves three major steps digestion, oxalate precipitation and permanganate titration.

Digestion: Sample $(2 \mathrm{~g})$ was suspended in $190 \mathrm{~mL}$ of distilled water in a $250 \mathrm{~mL}$ volumetric flask. To this, $10 \mathrm{~mL}$ of $6 \mathrm{M} \mathrm{HCl}$ was added and the suspension digested at $100^{\circ} \mathrm{C}$ for 1 hour, cooled and made up to $250 \mathrm{~mL}$ mark before filtration.

Oxalate Precipitation: Duplicate portions of $125 \mathrm{~mL}$ of the filtrate were measured into beakers and four drops of methyl red indicator added. This was followed by the addition of conc. $\mathrm{NH}_{4} \mathrm{OH}$ solution (drop wise) until the test solution changed from salmon pink colour to a faint yellow colour ( $\mathrm{pH} 4-4.5)$. Each portion was then heated to $90^{\circ} \mathrm{C}$, cooled and filtered to remove precipitate containing ferrous ion. The filtrate was again heated to $90^{\circ} \mathrm{C}$ and $10 \mathrm{~mL}$ of $5 \% \mathrm{CaCl}_{2}$ solution added while being stirred constantly. After heating, it was cooled and left overnight at $5^{\circ} \mathrm{C}$. The solution is then centrifuged at $2500 \mathrm{rpm}$ for 5 minutes. The 
supernatant was decanted and the precipitate completely dissolved in $10 \mathrm{ml}$ of $20 \%(\mathrm{v} / \mathrm{v})$ $\mathrm{H}_{2} \mathrm{SO}_{4}$ solution.

Permanganate Titration: The total filtrate resulting from digestion of $2 \mathrm{~g}$ of test sample was made up to $300 \mathrm{~mL}$. Aliquots of $125 \mathrm{~mL}$ of the filtrate was heated until near-boiling and then titrated against $0.05 \mathrm{M}$ standardized $\mathrm{KMnO}_{4}$ solution to a faint pink colour which persists for 30 seconds. The calcium oxalate content was calculated using the formula.

$$
\text { Oxalate }\left(\frac{\mathrm{mg}}{100 \mathrm{~g}}\right)=\frac{\mathrm{T} \times(\mathrm{Vme})(\mathrm{Df}) \times 10^{5}}{(\mathrm{ME}) \times(\mathrm{Mf})}
$$

Where $\mathrm{T}$ is the titre of $\mathrm{KMnO}_{4}(\mathrm{ml}), \mathrm{Vme}$ is the volume - mass equivalent $\left(1 \mathrm{~cm}^{3}\right.$ of $0.05 \mathrm{M}$ $\mathrm{KMnO}_{4}$ solution is equivalent to $0.00225 \mathrm{~g}$ anhydrous oxalic acid), Df is the dilution of factor $\mathrm{VT}_{\mathrm{T}} \mathrm{A}\left(2.4\right.$ where $\mathrm{V}_{\mathrm{T}}$ is the total volume of titrate $(300 \mathrm{~mL})$ and $\mathrm{A}$ is the aliquot used $(125 \mathrm{~mL}), \mathrm{ME}$ is the molar equivalent of $\mathrm{KMnO}_{4}$ in oxalate $\left(\mathrm{KMnO}_{4}\right.$ redox reaction) and $\mathrm{Mf}$ is the mass of the test sample used.

\subsubsection{Flavonoids (Extraction and Analysis)}

Plant sample (1.5g) was weighed into a set of extraction tube(s) and $20 \mathrm{ml}$ of boiled ultra-pure water dispensed into each extraction tubes. The setup was allowed to stand for 1.5 hours and voltexed for 5 minutes. The solution was transferred to a set of centrifuge tubes, shaked for 15 minutes and centrifuged for 5 minutes at $3000 \mathrm{rpm}$. Thereafter, a set of vials were used to collect the supernatants for determination on water 616/626 HPLC. The conditions for the analysis of flavonoids were as follows: (i) An autosampler (ii) An automated gradient controller (iii) Gradient elution HPLC pump (iv) Reverse-phase HPLC column, thermostatically heated in a temperature-controlled room. (v) Detector by fluorescence (vi) Carrier gas: Nitrogen gas at flow rate of $60 \mathrm{ml} / \mathrm{min}$. (vii) Temperature: Detector- $147^{\circ} \mathrm{C}$; Injector port- $166^{\circ} \mathrm{C}$ and Column: $115^{\circ} \mathrm{C}$ (viii) Computer facilities for storing data. (ix) Printer for results reporting

\subsubsection{Alkaloids (Extraction and Analysis)}

Ten gram $(10 \mathrm{~g})$ of plant sample was de-fated, out of which $5 \mathrm{~g}$ was weighed into a flask and $100 \mathrm{~mL}$ of $12 \%$ alcohol added, shaked, filtered and washed with industrial alcohol. The extracted residue was washed into a flask with $50 \mathrm{ml}$ of ammonia water (ultrapure water) and heated in boiling water for 20 minutes and allowed to cool. Then, $0.1 \mathrm{~g}$ of diastase (+ water) added and maintain at $50-55^{\circ} \mathrm{C}$ for $2 \mathrm{hrs}$. It was cooled and made up to $250 \mathrm{~mL}$ with ultrapure water, swirled and filtered. The filtrate $(200 \mathrm{~mL})$ was mixed with $20 \mathrm{~mL}$ hydrochloric acid (sp.g. 1.125) and heated in boiling water for 3 hours. Thereafter, it was allowed to cool, neutralized with sodium hydroxide solution and made up to $250 \mathrm{~mL}$. The sample was shaked, centrifuged and supernatant decanted for determination using water 616/626 HPLC. The conditions of HPLC (Water 616/626) for the analysis of alkaloids were as follows: (i) An autosampler (ii) An automated gradient controller (iii) Gradient elution HPLC pump (iv) Reverse-phase HPLC column, thermostatically heated in a temperature-controlled room. (v) 


\section{Macrothink}

Journal of Agricultural Studies

ISSN 2166-0379

2017, Vol. 5, No. 4

Detector by fluorescence (vi) Carrier gas: Nitrogen gas at flow rate of $40 \mathrm{~mL} / \mathrm{mins}$. (vii) Temperature: Detector- $170^{\circ} \mathrm{C}$; Injector port- $190^{\circ} \mathrm{C}$ and Column- $125^{\circ} \mathrm{C}$ (viii) Computer facilities for storing data. (ix) Printer for results reporting

\section{Results and Discussion}

The presence and concentration of phytochemicals in T. occidentalis grown in NM and HS are presented in Table I. Tannin, saponin and phytate contents of T. occidentalis were (1.290 ppm, $6.829 \mathrm{ppm}$ and $9.774 \mathrm{ppm}$ ) and (2.584 ppm, $7.253 \mathrm{ppm}$ and $8.857 \mathrm{ppm}$ ) for NM and HS, respectively. The hydrogen cyanide remained constant in both media while the trypsin-inhibitor were $1.290 \mathrm{ppm}$ and $2.584 \mathrm{ppm}$ for NM and HS, respectively. Kuku et al. (2014) reported that trypsin-inhibitors remain sensitive to heat and gradually or totally loses shape due to high temperature. According to Tsao and Akhtar (2005), some phytochemicals have the potential to act as antioxidant. Also, Young et al. (2005) suggested that phytochemicals have capacity to act as a chemo-preventive measure to human cancer by controlling the cell cycle, spread and initiation of apoptosis. Vegetables and fruits are the greatest sources of phytochemicals (Schippers, 2000; Liu, 2004). Jack and Nna (2015) reported $18.716 \mathrm{ppm}, 4.95 \mathrm{ppm}$ and $0.2243 \mathrm{ppm}$ for tannin, saponin and phytate content on $T$. occidentalis in that order while oxalate was not detected. However, this study detected oxalate in T. occidentalis grown in hydroponic medium $(5.897 \mathrm{ppm})$ and geoponic medium (5.927 ppm). The presence of saponin is well documented in some underutilized plants in Nigeria (Akundu, 1984; Edeoga et al., 2006; Belewu, et al., 2009). Studies have shown the existence of considerable variation in tannin concentrations from one plant to another (Gonzalez-Hernandez et al., 2003) and tannin content of a species is dependent on soil pH (Nicolai, 1988; Northup et al., 1995) and soil fertility (Keinanen et al., 1999). However, it has been reported that leaves containing tannins can be used for the treatment of intestinal disorder (Akindahunsi and Salawu, 2005). Also, tannins are said to be the source of aroma in tea and its astringent properties makes it suitable for the management of skin epidemic and other therapeutic purposes (Dutta, 2003).

Table I. Phytochemicals present in T. occidentalis grown in soilless and soil medium.

\begin{tabular}{ccc}
\hline Phytochemicals & \multicolumn{2}{c}{ Growth medium } \\
\cline { 2 - 3 }$(\mathrm{ppm})$ & $\mathrm{NM}$ & $\mathrm{HS}$ \\
& & \\
\hline Hydrogen cyanide (HCN) & 0.001 & 0.001
\end{tabular}




\begin{tabular}{lcc} 
Oxalate & 5.897 & 5.927 \\
Phytate & & \\
& 9.774 & 8.857 \\
Saponin & 6.829 & 7.253 \\
& & \\
Tannin & 2.546 & 2.127 \\
& & \\
Trypsin-inhibitor & 1.290 & 2.584 \\
\hline & & \\
\hline represents Soil medium; NM represents Soilless medium
\end{tabular}

HS represents Soil medium; NM represents Soilless medium

Flavonoids: The presence of 36 flavonoids ( 8 flavones, 3 isoflavones, 12 flavanones, 8 flavan-3-ols, 4 flavonols, and 1 anthocyanin) were detected in the leaves of T. occidentalis (Table II). The most abundant flavonoids in T. occidentalis was epigallocatechin followed by daidzein and catechin for NM while the sequence for HS was daidzein, catechin and genistein. Maeda et al. (2003) reported that the presence of catechins in tea helps to prevent the spread of the smooth muscle cells in the arterial wall thereby reducing the development of the atheromatous injury. Catechin has been reported to be the dominant scavenger among subgroups of flavonoids, comprises of two benzene rings structurally and frequently used as reference point in the determination of flavonoids contents in leaves (Hue et al., 2012). Consumption of flavonoids could be related to decline of having tumour, heart and inflammatory disorder in living organisms. Flavonoids can be derived from food containing vegetables (Haytowitz et al., 2003). Studies have shown that flavonoids (daidzein, genistein or their glycosides) supplemented meal have the capacity to stop bone damage and trabecular size triggered by ovarietomy (Nakajima et al., 2001). Smith et al. (2004) reported that genistein enhances the lung of patients suffering from asthma. According to Kumar et al. (2014), these flavonoids possess resistant to micro-organisms and significant antioxidative activity. They also reported that flavones and flavonols are abundant amongst the subgroups of flavonoids. However, the study showed more of flavanones when compared to others in $T$. occidentalis. The total flavonoids (10.019 g/100g NM, $8.064 \mathrm{~g} / 100 \mathrm{~g}$ HS) obtained in $T$. occidentalis using HPLC were higher compared to the works of Chibueze and Akubugwo (2011), Aminu et al. (2012) and Otitoju et al. (2014), with values of $6.67 \mathrm{~g} / 100 \mathrm{~g}, 0.84 \mathrm{~g} / 100 \mathrm{~g}$ and $0.07 \mathrm{~g} / 100 \mathrm{~g}$, respectively in same plant. Stefova et al. (2003) reported that flavonoids play crucial roles in biochemistry and physiology of plants. It is responsible for the biological effects of plants and their extracts as well as preparations on humans. Studies have suggested that flavonoids could confer defence against disorder like injury, cancer, aging, 


\section{Al Macrothink}

Journal of Agricultural Studies

ISSN 2166-0379

2017, Vol. 5, No. 4

atherosclerosis, inflammation and neurodegenration by boosting antioxidant of the body immune system (Pal et al., 2012; Dilipkumar and Preeti, 2013). The anthocyanin content $(0.082 \mathrm{~g} / 100 \mathrm{~g})$ was higher than the result obtained by Onyeka and Nwambekwe $(0.02$ $\mathrm{g} / 100 \mathrm{~g}$ ). However, the low anthocyanin content was expected among vegetables because anthocyanin is usually more in vegetables and fruits without green pigmentation (Dewanto et al., 2002). According to Scalbert et al. (2005), the formation of tumour, diabetes, heart and neurodegenerative disorder can be prevented by anthocyanin intake. Also, flavonoids have several health benefits (Brodowska, 2017). Flavonoids are indeed essential to human system. Studies have shown that flavonoids play a similar role in the human body as vitamins (Ostrowska and Skrzydlewska, 2005; Mitek and Gasik, 2009).

Table II. Flavonoids composition of T. occidentalis grown in soilless and soil medium.

Subgroups of flavonoids $\quad$ Flavonoids $(\mathrm{g} / 100 \mathrm{~g}) \quad$ Growth medium

$\mathrm{NM} \quad \mathrm{HS}$

Flavones

Apigenin

0.003

0.000

Luteolin

0.096

0.007

Nobiletin

$0.001 \quad 0.001$

Tangeretin

$0.005 \quad 0.005$

Diosmin

$0.003 \quad 0.002$

Rhoifolin

$0.015 \quad 0.020$

Neodiosmin

$0.013 \quad 0.019$ 
Acacetin

$0.017 \quad 0.009$

Sinensetin

$0.017 \quad 0.018$

Isofavones

Daidzein

2.546

2.308

Genistein

1.076

1.222

Glycetin

0.246

0.201

Flavanones

Eriodictyol

0.026

0.053

Hesperetin

$0.009 \quad 0.009$

Hesperidin

$0.012 \quad 0.006$

Nanirutin

$0.015 \quad 0.007$

Naringin

$0.021 \quad 0.022$

Naringenin

0.002

0.003

Raxifolin

$0.004 \quad 0.009$ 
Taxifolin

Didymin

Eriocitrin

Neoeriocitin

Poncirin

0.009

0.009

Flavan-3-ols

Catechin

1.718

1.555

Epicatechin

0.965

1.200

Epicatechin gallate

$0.015 \quad 0.009$

Epigallocatechin

2.620

0.991

Epigallocatechin gallate

0.01

0.011

Theaflavins

0.140

0.090

Thearubigins

0.049

0.047

Proanthocyanidins
$0.023 \quad 0.015$ 
Flavonols

Flavonols

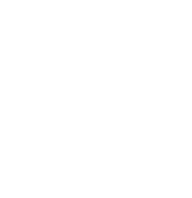

Kaempferol

0.000

0.002

0.032

0.026

Anthocyanin

Anthocyanin

0.082

0.083
0.002

Myricetin

0.003

Quercetin

Isorharmnetin

(1)

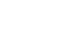

\begin{abstract}
Anthocyanin
\end{abstract}
Total Flavonoids

\section{$10.019 \quad 8.064$}

HS represents Soil medium; NM represents Soilless medium

Alkaloids: Forty five alkaloids were identified by HPLC (Table III). Quinoline (4.221 g/100g $\mathrm{NM} ; 3.610 \mathrm{~g} / 100 \mathrm{~g} \mathrm{HS}$ ) and emetine (2.721 g/100g NM; $2.014 \mathrm{~g} / 100 \mathrm{~g}$ HS) were determined as the most abundant alkaloids in the leaves of T. occidentalis while apoatropine, ephedrine, eserine, narcotine, psychotrine and theobromine were the least $(0.001 \mathrm{~g} / 100 \mathrm{~g})$. All the alkaloids in T. occidentalis varied in the different growth medium. The total alkaloids (11.614 g/100g NM, $9.082 \mathrm{~g} / 100 \mathrm{~g}$ HS) obtained in T. occidentalis using HPLC was higher compared to other works (Onyeka and Nwambekwe, 2007; Otitoju et al., 2014; Odufuwa et al., 2013), which reported $0.81 \mathrm{~g} / 100 \mathrm{~g}, 0.04 \mathrm{~g} / 100 \mathrm{~g}$ and $0.039 \mathrm{~g} / 100 \mathrm{~g}$, respectively for total alkaloids in T. occidentalis. Also, Oduse et al. (2012) reported $13.83 \mathrm{mg} / \mathrm{kg}$ for Cnidoscolus aconitifloina and $10.13 \mathrm{mg} / \mathrm{kg}$ for Vernonia amygdalina. However, the results showed that T. occidentalis leaf in NM contained a high amount of alkaloids than in HS. Alkaloids are involved in prevention of bacterial species from causing harm to a system (Nuhu et al., 2000; Tor-Anyiin, 2009). Alkaloids such as caffeine affects the central nervous system particularly on the gaps 


\section{Macrothink}

Journal of Agricultural Studies

ISSN 2166-0379 2017, Vol. 5, No. 4

between nerve cells in the conduits of the nervous system. Alkaloids are generally soluble in lipids and this account for its relevance (Lewis and Elvin-Lewis, 1998).

Table III. Alkaloids composition of T. occidentalis grown in soilless and soil medium.

\begin{tabular}{|c|c|c|c|}
\hline \multirow[t]{2}{*}{ Group of alkaloids } & \multirow[t]{2}{*}{ Alkaloids (g/100g) } & \multicolumn{2}{|c|}{ Growth medium } \\
\hline & & NM & HS \\
\hline \multirow[t]{4}{*}{ Tropane alkaloids } & Apoatropine & 0.001 & 0.005 \\
\hline & Atropine & 0.015 & 0.015 \\
\hline & Hyoscine & 0.020 & 0.022 \\
\hline & Cocaine & 0.013 & 0.012 \\
\hline Acridine alkaloids & Acridine & 0.011 & 0.009 \\
\hline \multirow[t]{4}{*}{ Quinoline alkaloids } & Cinchonidine & 0.002 & 0.003 \\
\hline & Cinchonine & 0.012 & 0.016 \\
\hline & Quinidine & 1.220 & 0.877 \\
\hline & 190 & \multicolumn{2}{|c|}{ http://jas.macrothink.org } \\
\hline
\end{tabular}


Quinine

Quinoline

Indole/benzypyrole alkaloids $\quad \beta$-carboline

Ergotamine

Eserine

Rauwolfia

Reserpine

Strychnine

Vinca alkaloids

Vinblastine

Vincristine

Isoquinoline alkaloids
Berberine

0.005
0.001

$4.221 \quad 3.610$

$0.009 \quad 0.008$

$0.019 \quad 0.017$

$0.002 \quad 0.001$

$0.009 \quad 0.009$

$1.821 \quad 0.950$

$0.036 \quad 0.074$

$0.766 \quad 0.426$

$0.109 \quad 0.054$ 
Codeine

Cephaline

Heroin

Emetine

Morphine

Narcotine

Papaverine

Psychotrine

Tubocurarine

Apomorphine

Purine (Pseudo) alkaloids

Caffeine

Theobromine

Theophylline
$0.009 \quad 0.005$

$0.012 \quad 0.007$

$0.080 \quad 0.082$

$2.721 \quad 2.014$

$0.010 \quad 0.014$

$0.001 \quad 0.001$

$0.015 \quad 0.015$

$0.001 \quad 0.001$

$0.004 \quad 0.085$

$0.003 \quad 0.003$

$0.008 \quad 0.009$

$0.001 \quad 0.001$

$0.007 \quad 0.005$ 
$\beta$-Phenylethylamine alkaloids

Ephedrine

$0.001 \quad 0.003$

Norpseudoephedrine

$0.009 \quad 0.009$

Colchicine alkaloids

Colchicine

$0.008 \quad 0.011$

Piperidine alkaloids

Coniine

$0.013 \quad 0.029$

Lobeline

$0.070 \quad 0.059$

Piperine

$0.027 \quad 0.022$

Pyridine alkaloids

Nornicotine

$0.021 \quad 0.012$

Pyridine

$0.050 \quad 0.048$

Ricinine

$0.002 \quad 0.005$ 


\section{Nicotine \\ 0.144 \\ 0.293}

Pelletierine

0.095

0.211

Imidazole alkaloids

Pilocarpine

0.001

0.003

Total alkaloids

11.614

9.082

HS represents Soil medium; NM represents Soilless medium

\section{Conclusion}

The phytochemical profile of $T$. occidentalis grown in soil and soilless media revealed the inherent potentials and the comparative advantage of soilless medium over soil medium. Phytochemical content of $T$. occidentalis leaf varied in soilless and soil media. Soilless medium provides an alternative in improving the bioactive components and growing leafy vegetables. However, the hydrogen cyanide was the same in hydroponic and geoponic systems.

\section{References}

Aminu, M., Bello, M. S., Abba, O., Aliyu, M., Malam, B. S., Auwalu, G., Hafsat, A. M., Shafi'u. M., Hussaina, N. N., Hasiya, A., \& Sani, A. (2012). Comparative in vitro Antioxidant Studies of Ethanolic Extracts of Psidium guajava Stem Bark and Telfairia occidentalis Leaf. International Journal of Modern Biochemistry, 1(1): 18-26.

Akindahunsi, A. A., \& Salawu, S. O. (2005). Phytochemical screening of nutrient and antinutrient composition of selected tropical green leafy vegetables. African Journal of Biotechnology, 4: 497-501.

Akundu, M. N. (1984). An investigation of anti-abortive properties of the leaves of Ocimium gratisimum. M.Sc. Thesis, University of Nigeria, Nsukka, Nigeria, 1984.

Ayandele, A., \& Adebiyi, A. O. (2007). Antimicrobial Screening of extracts of Olax Subscorpiodes. African Journal of Biotechnology, 6(7): 868-870. 
Belewu, M. A., Olatunde, O. A., \& Giwa, T. A. (2009). Underutilized medicinal plants and spices: Chemical composition and phytochemical properties. Jour. Med. Plants Res., 3(12): 1099-1103.

Brodowska, K. M. (2017). Natural flavonoids: classification, potential role and application of flavonoids analogues. European Journal of Biological Research, 7(2): 108-123.

Chibueze, U., \& Akubugwo, E. I. (2011). Nutritive values and phytochemical contents of some leafy vegetables grown with different fertilizers. Agricultural and Biology Journal of North America, 2(12): 1437-1444. https://doi.org/10.5251/abjna.2011.2.12.1437.1444

Chu, Y. F., Sun, J., Wu, X., \& Liu, R. H. (2002). Anti-oxidant and anti-proliferative activities of common vegetables. Journal of Agricultural and Food Chemistry, 50: 6910-6916.

https://doi.org/10.1021/jf020665f

Chunmei, G., Pan, H., Sun, Z., \& Qin, G. (2010). Effect of soybean variety on anti-nutritional factors content, and growth parameters and nutrients metabolism in rat. Int. J. Mol. Sci., 11(3): 1048-1056. https://doi.org/10.3390/ijms11031048

Dewanto, V., Wu, X. and Liu, R. H. (2002). Processed sweet corn has higher antioxidant activity. Journal of Agricultural and Food Chemistry, 50: 4959-4964.

https://doi.org/10.1021/jf0255937

Dilipkumar, P., \& Preeti, V. (2013). Flavonoids: A powerful and abundant source of antioxidants. International Journal of Pharmacy and Pharmaceutical Sciences, 5(3): 95-98.

Dutta, A. C. (2003). Botany for Degree students (6th edu). Oxford University press. pp. 140 143

Edeoga, H. O., Omobuna, G., \& Uche, L. C. (2006). Chemical composition of Hyotis suaveoleus and Ocimium gratisimum hybrids from Nigeria. African Journal of Biotechnology, 5(1): 892-895.

Gonzalez-Hernandez, M. P., Karchesy, J., \& Starkey, E. E. (2003). Research observation: Hydrolyzable and condensed tannins in plants of northwest Spain forests. J. Range Management, 56: 461-465. https://doi.org/10.2307/4003837

Haytowitz, D. B., Eldridge, A. L., Bhagwat, S., Gebhardt, S. E., Holden, J. M., Beecher, G. R., Peterson, J., \& Dwyer, J. (2003). Flavonoid Content of Vegetables. International Research Conference on Food, Nutrition and Cancer, 17-18 July 2003, Washington, DC

Hue, S., Boyce, A. N., \& Somasundram, C. (2012). Antioxidant activity, phenolic and flavonoid contents in the leaves of different varieties of sweet potato (Ipomoea batatas). Australian Journal of Crop Science, 6(3): 375-380.

Iwu, M. W., Duncan, A. R., \& Okunji, C. O. (1999). New antimicrobials of Plant origin. Janick Journal of Education, 457-462.

Jack, I. R., \& Nna, P. J. (2015). Comparative studies of the phytochemical analysis of the methanolic extract of two Nigerian leaves - Telfairia occidentalis and Gongronema latifolium. 
European Journal of Biomedical and Pharmaceutical Sciences, 2(5): 38-45.

Kajihausa, O. E., Sobukola, O. P., Idowu, M. A., \& Awonorin, S. O. (2010). Nutrient contents and thermal degradation of vitamins in organically grown fluted pumpkin (Telfairia occidentalis) leaves. International Food Research Journal, 17: 795-807

Kaur, C., \& Kapoor, H. C. (2002). Antioxidant activity and total phenolic content in some Asian Vegetables. International Journal of Food Science and Technology, 37: 151-61.https://doi.org/10.1046/j.1365-2621.2002.00552.x

Keinanen, M., Julkunen-Tiito, R., Mutikainen, P., Walls, M., Ovacka, J., \& Vapaavuori, E. (1999). Trade-offs in phenolic metabolism of silver birch: Effects of fertilization, defoliation and genotype. Ecology, 80: 1970-1986.

https://doi.org/10.2307/176672https://doi.org/10.1890/0012-9658(1999)080[1970:TOIPMO] 2.0.CO;2

Kuku, A., Etti, U. J., \& Ibironke, I. S. (2014). Processing of flutted pumpkin seeds, Telfairia occidentalis (Hook f) as it affects growth performance and nutrient metabolism in rats. African Journal of Food, Agriculture, Nutrition and Development, 14(5): 1993-2014.

Kumar, H., Choudhary, N., Varsha, N., Kumar, S., \& Seth, R. (2014). Phenolic compounds and their health benefits: A review. Journal of Food Research and Technology, 2(2): 46-59.

Lewis, W. M., \& Elvin-Lewis, M. P. F. (1998). Plants affecting man's Health" Medical botany. John Wiley and sons.

Liu, R. H. (2004). Potential synergy of phytochemicals in cancer prevention: mechanism of action. Journal of Nutrition, 134: 34795-34855

Maeda, K., Kuzuya, M., Cheng, X. W., Asai, T., Kanda, S., Tamaya-Mori, N., Sasaki, T., Shibata, T., \& Ighuchi, A. (2003). Green tea catechins inhibit the cultured smooth muscle cell invasion through the basement barrier. Atherosclerosis, 166: 23-30.

https://doi.org/10.1016/S0021-9150(02)00302-7

Materska, M., \& Perucka, I. (2005). Antioxidant activity of the main phenolic compounds isolated from hot pepper fruit. Journal of Agricultural and Food Chemistry, 53: 1750-1756. https://doi.org/10.1021/jf035331k

Mitek, M., \& Gasik, A. (2009). Polyphenols in food. The impact on organoleptic characteristics of food [in Polish]. Przem Spoż., 5: 34-39.

Moran-Palacio, E. F., Tortoledo-Ortiz, O., Yanez-Farias, G. A., Zamora-Alvarez, L. A., Stephens-Camacho, N. A., Sonanez-Organis, J. G., Ochoa-Lopez, L. M., \& Rosas-Rodriguez, J. A. (2014). Determination of amino acids in medicinal plants from Southern Sonora, Mexico. Tropical Journal of Pharmaceutical Research, 13(4): 601-606. https://doi.org/10.4314/tjpr.v13i4.17

Nadeem, M., Anjum, F. M., Khan, M. R., Saeed, M., \& Riaz, A. (2011). Antioxidant potential of bell pepper (Capsicum annuum L). Pakistan Journal of Food Science, 21: 45-51. 


\section{Al Macrothink}

Journal of Agricultural Studies

ISSN 2166-0379

2017, Vol. 5, No. 4

Nakajima, D., Kim, C. S., Oh, T. W., Yang, C. Y., Naka, T., Igawa, S., \& Ohta, F. (2001). Suppressive effects of genistein dosage and resistance exercise on bone loss in ovariectomized rats. Journal Physiological Anthropology and Applied Human Science, 20: 285-291. https://doi.org/10.2114/jpa.20.285

Nicolai, V. (1988). Phenolic and mineral content of leaves influences decomposition in European forest ecosystems. Oecologia, 75: 575-579. https://doi.org/10.1007/BF00776422

Northup, R. R., Dahlgren, R. A., \& Yu, Z. (1995). Intraspecific variation of conifer phenolic concentration on a marine terrace soil acidity gradient; a new interpretation. Plant Soil, 171: 255-262. https://doi.org/10.1007/BF00010279

Nuhu, A. M., Mshelia M.S., \& Yakubu Y. (2000). Antimicrobial screening of the bark extract of Pterocarpus erinaceus tree. J. Chem. Soc. Nig., 28: 85-87.

Odufuwa, K. T., Daramola, G. G., Adeniji, P. O., \& Salau, B. A. (2013). Changes in Alkaoids Content of Some Selected Nigerian Vegetables during Processing. IOSR Journal of Dental and Medical Sciences, 6(1): 51-54. https://doi.org/10.9790/0853-0615154

Oduse, K. A., Idowu, M. A., \& Adegbite, A. A. (2012). Chemical and phytochemical profile of some uncommon green leafy vegetables consumed in south west, Nigeria. IOSR Journal of Environmental Science, Toxicology and Food Technology, 1(3): 22-26.

Onyeka, E. U., \& Nwambekwe, I. O. (2007). Phytochemical profile of some green leafy vegetables in South-East Nigeria. Nigerian Food Journal, 25(1): 67-76.

https://doi.org/10.4314/nifoj.v25i1.33655

Onyeka, E. U., Agha, J. C., \& Nwanjo, A. C. (2010). Phytochemical, nutrient and antinutrient contents of Cnidoscolus aconitifolius, a lesser known green leafy vegetables. Nigerian Food Journal, 28(2): 14-24. https://doi.org/10.4314/nifoj.v28i2.62631

Ostrowska, J., \& Skrzydlewska, E. (2005). Biological activity of flavonoids [in Polish]. Post Fitoter, 3(4): 71-79.

Otitoju, G. T. O., Nwamarah, J. U., Otitoju, O., Odoh, E. C., \& Iyeghe, L. U. (2014). Phytochemical composition of some underutilised green leafy vegetables in Nsukka urban LGA of Enugu State. Journal of Biodiversity and Environmental Sciences, 4(4): 208-217.

Pal, D., Saha, S., \& Singh, S. (2012). Importance of pyrazolemolety in the field of cancer. International Journal of Phar., 4(2): 98-104.

Scalbert, A., Manach, C., Morand, C., Remesy, C., \& Jimenez, L. (2005). Dietary polyphenols and the prevention of diseases. Crit. Rev. Food Sci., 45: 287-306.

https://doi.org/10.1080/1040869059096

Schipper, R. R. (2000). African indigenous vegetable-An overview of the cultivated species. Chatham, UK: NRI/CAT. 231

Smith, L. J., Holbrook, J. T., Wise, R., \& Blumenthal, M. (2004). Dietary intake of soy genistein is associated with lung function in patients with asthma. Journal of Asthma, 41: 


\section{Macrothink}

Journal of Agricultural Studies

ISSN 2166-0379

2017, Vol. 5, No. 4

833-843. https://doi.org/10.1081/JAS-200038447

Stefova, M., Stafilov, T., \& Kulevanova, S. (2003). HPLC analysis of flavonoids. Encyclopedia of chromatography. Marcel Dekker Inc. New York, pp 1-7.

Tor-Anyiin, T.A. (2009). Chemical characterisation of stem bark of Sterculia setigera. Ph.D. Thesis, Nnamdi Azikiwe Univ., Awka, Nigeria.

Tsao, R., \& Akhtar, M. H. (2005). Nuetraceuticals and functional foods: I. Current trend in phytochemical antioxidant research. J. Food Agric. Environ. 3: 10-17.

Velioglu, Y. S., Mazza, G., Gao, L., \& Oomah, B. D. (1998). Antioxidant activity and total phenolics in selected fruits, vegetables and grain products. Journal of Agricultural and Food Chemistry, 46: 4113-4117. https://doi.org/10.1021/jf9801973

Young, J. E., Zhao, X., Carey, E. E., Welti, R., Yang, S. S., \& Wang, W. (2005). Phytochemical phenolics in organically grown vegetables. Molecular Nutrition and Food Research, 49: 1136-1142. https://doi.org/10.1016/j.phytochem.2004.12.004

Zhou, J. R., \& Erdman, J.W. (1995): Phytic acid in health and disease. Critical Reviews of Food Science and Nutrition, 35, 495-508. https://doi.org/10.1080/10408399509527712

\section{Copyright Disclaimer}

Copyright for this article is retained by the author(s), with first publication rights granted to the journal.

This is an open-access article distributed under the terms and conditions of the Creative Commons Attribution license (http://creativecommons.org/licenses/by/4.0/). 